\title{
Impact of river current on the uniformity of littoral communities of Rotifera
}

\author{
Jolanta Ejsmont-Karabin, Piotr Zieliński \\ Department of Hydrobiology, Institute of Biology, University of Białystok, Świerkowa 20 B, 15-950 Białystok, Poland, \\ e-mail: jolanta@onet.pl (corresponding author)
}

\begin{abstract}
Studies were carried out in September 2007 at a set of stations called RIVERS located on two tributaries of the Narew River, and six stations on the tributaries of the Supraśl River. Concurrently, rotifers were sampled at nine stations of the River Rudnia (called RUDNIA). The aim of the research was the verification of the hypothesis on the uniforming effect of the river drift on rotifer communities inhabiting aquatic vegetation. The total numbers of all monogonont species inhabiting aquatic vegetation of RUDNIA and RIVERS were 83 and 107, respectively. The percentage similarity of rotifer communities from aquatic vegetation and river current at the same stations was relatively low and only slightly higher in RIVERS (21.7\%) than RUDNIA (17.1\%), which suggests that species composition of communities of epiphytic rotifer fauna has a rather low impact on species structure of rotifer communities in water drift. The set of individuals of different species carried with the water current was random and various at different stations. Although the percentage similarity of rotifer communities in the river drift calculated for all possible pairs of the stations was relatively lower in RIVERS than in RUDNIA, it was not reflected in the similarity of epiphytic rotifer communities, which were similar in both sets of stations. Thus, the hypothesis cannot be confirmed by the results of this research.
\end{abstract}

Key words: rotifera, river, restoration, drift.

\section{Introduction}

Macrophytes in lotic ecosystems may benefit invertebrates by providing them with substrate for epiphytic algae (=food), refuge from predators and niches (Shupryt and Stelzer 2009). Modenutti and Claps (1989) studying monogononts in 14 rivers in Rio de la Plata Estuary basin (Argentina) have shown that plankton communities were characterized by changing dominant species and high differences in species composition of rotifer fauna at different sampling stations, whereas periphyton communities were more homogenous in time and space. It may be confirmed by the results of Nielsen and Watson's (2008) studies on slackwater experimental habitats. They suggest that populations of microfauna inhabiting these habitats have strategies that enable them to cope with a disturbance and to recolonize newly created slackwater sites. It is also suggested that in rivers, diversity and composition of the rotifer communities in the pelagic and littoral habitats are similar (Duggan 2001). However, in fast flowing rivers rotifers may be absent in locations without periphyton and occur in high numbers of species and abundance in those with periphyton (Erben 1987). According to Lair and Reyes-Marchant (1997) the lower river regions are progressively enriched by successive inoculates, dilution and seeding inputs, which enable rotifers to colonize other sites.

The main aim of the research was the verification of the hypothesis on the uniforming effect of the river drift on rotifer communities inhabiting aquatic vegetation.

\section{Study area}

The Rudnia River is a small, second-order river in the periglacial landscape of the north-east part of Poland. It is the right tributary of the Narew River, flowing from north to south (Table 1). The Rudnia River arises in Pasynki village (160 m a.s.l.), and is surrounded by a catchment dominated by agricultural management. Average discharge during the period of 
Table 1A. Description of the studied rivers

\begin{tabular}{|c|c|c|c|c|c|}
\hline \multirow{2}{*}{ River } & \multirow{2}{*}{ Inflow into } & River length & Watershed area & Forest cover & Mean slope \\
\hline & & {$[\mathrm{km}]$} & {$\left[\mathrm{km}^{2}\right]$} & {$[\%]$} & {$[\% 0]$} \\
\hline Supraśl 1 & Narew & 20.4 & 211 & 86.3 & 0.51 \\
\hline Supraśl 2 & Narew & 106.5 & 1856 & 50.1 & 0.62 \\
\hline Radulinka & Supraśl & 6.2 & 18 & 91.8 & 0.66 \\
\hline Słoja & Supraśl & 23.0 & 225 & 38.3 & 0.66 \\
\hline Sokołda & Supraśl & 57.5 & 487 & 47.3 & 0.72 \\
\hline Płoska & Supraśl & 23.6 & 216 & 68.1 & 0.84 \\
\hline Jałówka & Supraśl & 5.4 & - & - & 0.65 \\
\hline Pilnica & Supraśl & 10.1 & 35 & 80.7 & 0.49 \\
\hline
\end{tabular}

Table 1B. Description of the studied sites along the Rudnia River

\begin{tabular}{|c|c|c|c|c|}
\hline \multirow{2}{*}{ Site No } & River length & Watershed area & Forest cover & Mean slope \\
\hline & {$[\mathrm{km}]$} & {$\left[\mathrm{km}^{2}\right]$} & {$[\%]$} & {$[\% 0]$} \\
\hline Rudnia 1 & 8.91 & 35.49 & 5.68 & 1.54 \\
\hline Rudnia 2 & 15.29 & 48.05 & 7.05 & 1.25 \\
\hline Rudnia 3 & 20.53 & 63.62 & 11.56 & 1.05 \\
\hline Rudnia 4 & 22.75 & 82.37 & 18.21 & 1.13 \\
\hline Rudnia 5 & 24.59 & 86.22 & 18.42 & 0.68 \\
\hline Rudnia 6 & 26.2 & 87.43 & 18.5 & 0.47 \\
\hline Rudnia 7 & 27.06 & 88.47 & 18.61 & 0.58 \\
\hline Rudnia 8 & 28.01 & 89.21 & 18.92 & 0.59 \\
\hline Rudnia 9 & 28.8 & 90.57 & 19.09 & 0.72 \\
\hline
\end{tabular}
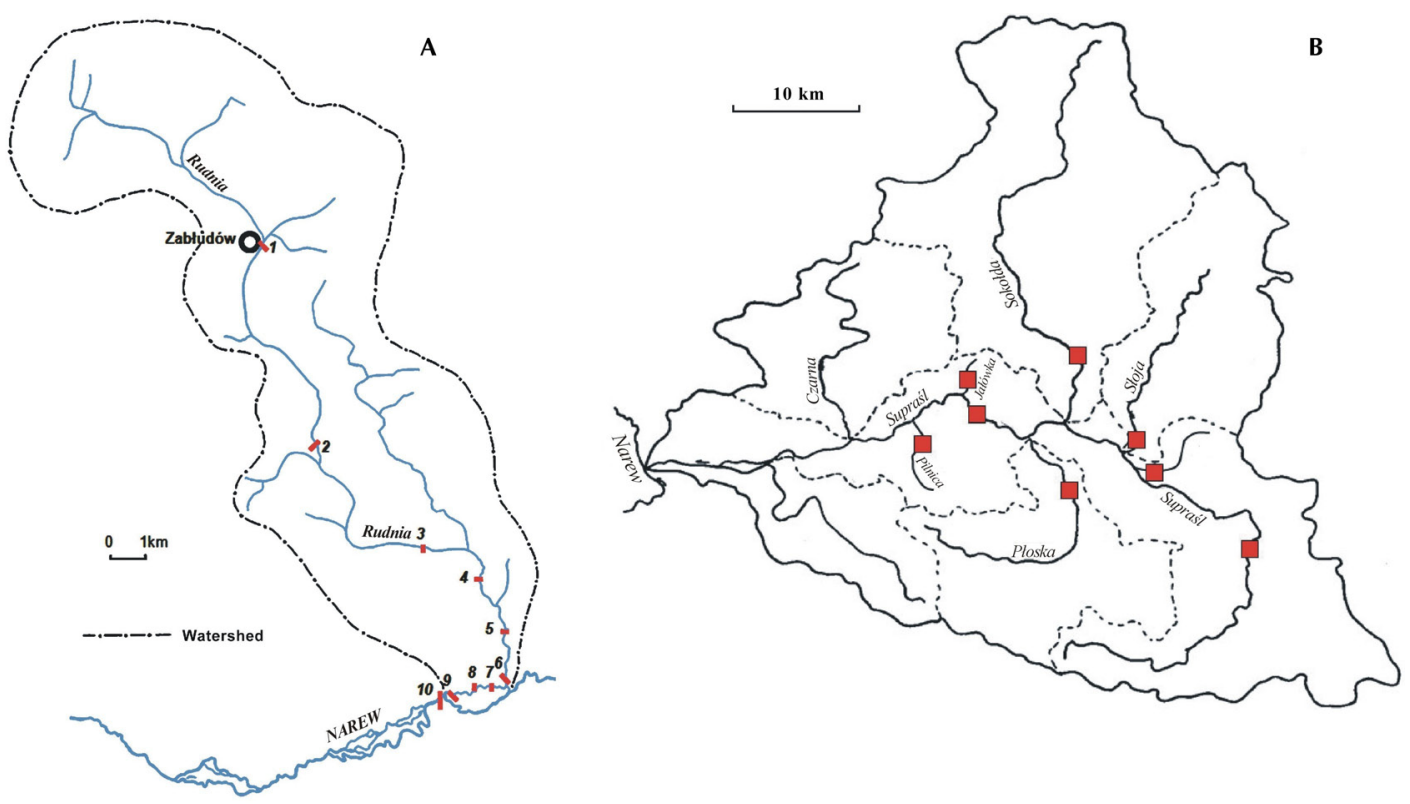

Fig. 1. Location of the sampling points in RUDNIA (A) and RIVERS (B) 
the study was $0.2 \mathrm{~m}^{3} \mathrm{~s}^{-1}$. The bottom sediments are mosaic and consist of sand, clay and gravel. Mean catchment slope is very small and typical for this region (Fig. 1A). The most commonly noted submerged plants on both groups of investigated sites were $\mathrm{Nu}$ phar lutea (L.), Elodea canadensis Michx., Myriophylum spicatum L., Callitriche palustris L.

The first-order rivers - Radulinka, Słoja, Sokołda, Płoska, Jałówka and Pilnica - are small rivers, tributaries of the Supraśl River. All these rivers are characterized by the very small area of their catchment and slope. Most of them have very similar hydromorphological characteristics to the Rudnia River. The Supraśl River is a second-order river, a tributary of the Narew River (Fig. 1B).

\section{Methods}

Studies were carried out in September 2007 at two stations located on small rivers, tributaries of the Narew River, and six stations on the tributaries of the Supraśl River (called RIVERS). Concurrently, rotifers were sampled at nine stations of the River Rudnia (called RUDNIA) (Table 1).

Samples taken from the water current and macrophytes were prepared separately. Plankton material was condensed on a plankton net of $30-\mu \mathrm{m}$ mesh size and preserved with formalin. Submerged macrophyte samples were taken from every station into separate containers. Three different, dominant species were sampled from each site. Epiphytic rotifers were removed from macrophytes using a soft bristle brush, condensed on a plankton net of $30-\mu \mathrm{m}$ mesh size, transferred into bottles and preserved. The plant material devoid of epiphyton was dried overnight at $60^{\circ} \mathrm{C}$ and weighed.

The index of percentage similarity of community (PSC) (Whittaker and Fairbanks 1958) was used:

$$
P S C=100-0.5 \sum(a-b)=\sum \min .(a, b)
$$

where: $a$ and $b$ are percentages of individuals of each species in total numbers of the communities of river habitats A (current) and B (vegetation), compared in pairs.

An index of floral originality (Puchalski 1987) was used to assess the distinction of rotifer communities between the river stations:

$$
I F O=\frac{\sum \frac{1}{M}}{S}
$$

where: $M$ is the number of samples in which a species occurs; $S$ is the number of species in a sample.

Statistical analyses were run with STATISTICA (Statsoft. Inc.) software. Probability levels of $\leq 0.05$ were considered significant.

\section{Results}

Total numbers of all monogonont species inhabiting aquatic vegetation of RUDNIA and RIVERS were 83 and 107, respectively. However, numbers of species found at particular stations were lower and accounted for 12 to 42 with a mean of $29(S D=11)$ in RUDNIA and markedly more, i.e. 20 to 76 with the mean of 35 (SD = 19) in RIVERS. Nevertheless the differences between the two sets of data were statistically insignificant (t-test, $P=0.41$ ).

Abundance of rotifers inhabiting aquatic vegetation was very differentiated and ranged from 253 ind. $\mathrm{g}^{-1}$ DW of macrophytes in the River Supraśl to 4291 ind. $\mathrm{g}^{-1}$ DW in the River Sokołda and from 78 ind. $\mathrm{g}^{-1}$ DW at station 8 to 7349 at station 2 of the River Rudnia (Fig. 2). Mean densities of the epiphytic communities were $1516(\mathrm{SD}=1271)$ ind $\mathrm{dm}^{-3}$ in RIVERS and 1607 ( $\mathrm{SD}=2227$ ) ind. $\mathrm{dm}^{-3}$ in RUDNIA (Fig. 2). The differences between epiphytic rotifer numbers in the RIVERS and RUDNIA were not significant ( $\mathrm{t}-$ test, $P=0.92$ ). From among them monogonont species were markedly more abundant in RIVERS with the mean value of $1008(\mathrm{SD}=1084)$ ind. $\mathrm{g}^{-1} \mathrm{DW}$ than in RUDNIA (630 \pm 698 ind. $\left.\mathrm{g}^{-1} \mathrm{DW}\right)$. However, even in this case the differences between the two groups of stations are not significant $(P=0.40)$.

The communities were dominated by eight different species, six of them occurred in the RIVERS and four in RUDNIA: Lecane closterocerca (Schmarda) and Colurella colurus (Ehrenberg) dominated in both studied groups of stations, whereas Euchlanis dilatata Ehrenberg, E. lyra Hudson Colurella adriatica Ehrenberg and Lepadella quadricarinata (Stenroos) were dominants in RIVERS and Cephalodella exigua (Gosse) and Testudinella truncata (Gosse) in RUDNIA.

Total numbers of all monogonont species which drifted with water current in RUDNIA and RIVERS were 41 and 39, respectively. However, numbers of 


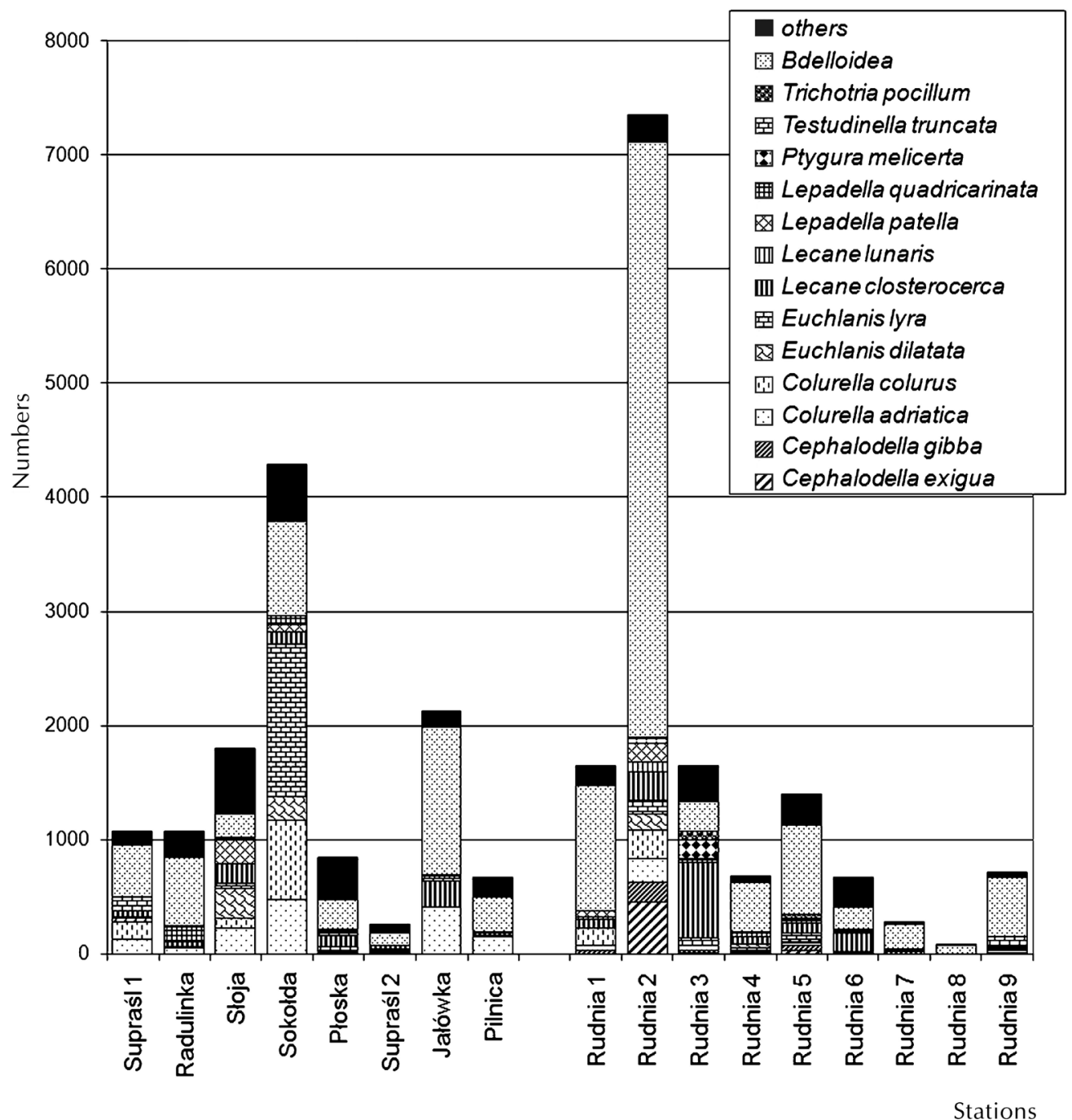

Fig. 2. Numbers of epiphytic Rotifera (ind. $\mathrm{dm}^{-3}$ ) at particular stations of the rivers under study in September 2007

species found at particular stations were markedly lower and accounted for 1 to 13 with a mean of 8 (SD $=4)$ in RUDNIA and 2 to 13 with the mean of 7 (SD $=4)$ in RIVERS.

Densities of rotifers in the water current were very low and differentiated (Fig. 3). They ranged from 2 ind. $\mathrm{dm}^{-3}$ (in Supraśl 1) to 393 ind. $\mathrm{dm}^{-3}$ (in Pilnica) in RIVERS and from 2 ind. $\mathrm{dm}^{-3}$ (st. 9) to 97 ind. $\mathrm{dm}^{-3}$ (st. 8) in RUDNIA. Keratella cochlearis (Gosse) and Lecane closterocerca were dominants common for both the studied rivers. Among dominants in the water current of RUDNIA there were also Colurella uncinata (Müller) and Mytilina mucronata (Müller), and in RIVERS Cephalodella exigua.
The percentage similarity of rotifer communities from aquatic vegetation and river current at particular stations was slightly higher in RIVERS (21.7 $\pm 15.3 \%)$ than RUDNIA $(17.1 \pm 12.9 \%)$ (Table 2). However, the differences between the particular stations were very high. A complete lack of common species was observed both in RIVERS and RUDNIA. There were also stations with a relatively large part of the rotifer community being the same in both habitats, like Jałówka among RIVERS (PSC $=43.4$ ) and station No. 2 in RUDNIA (PSC $=36.2$ ). As a result, the differences between PSC values for both sets of data were statistically not significant $(P=0.52)$. 


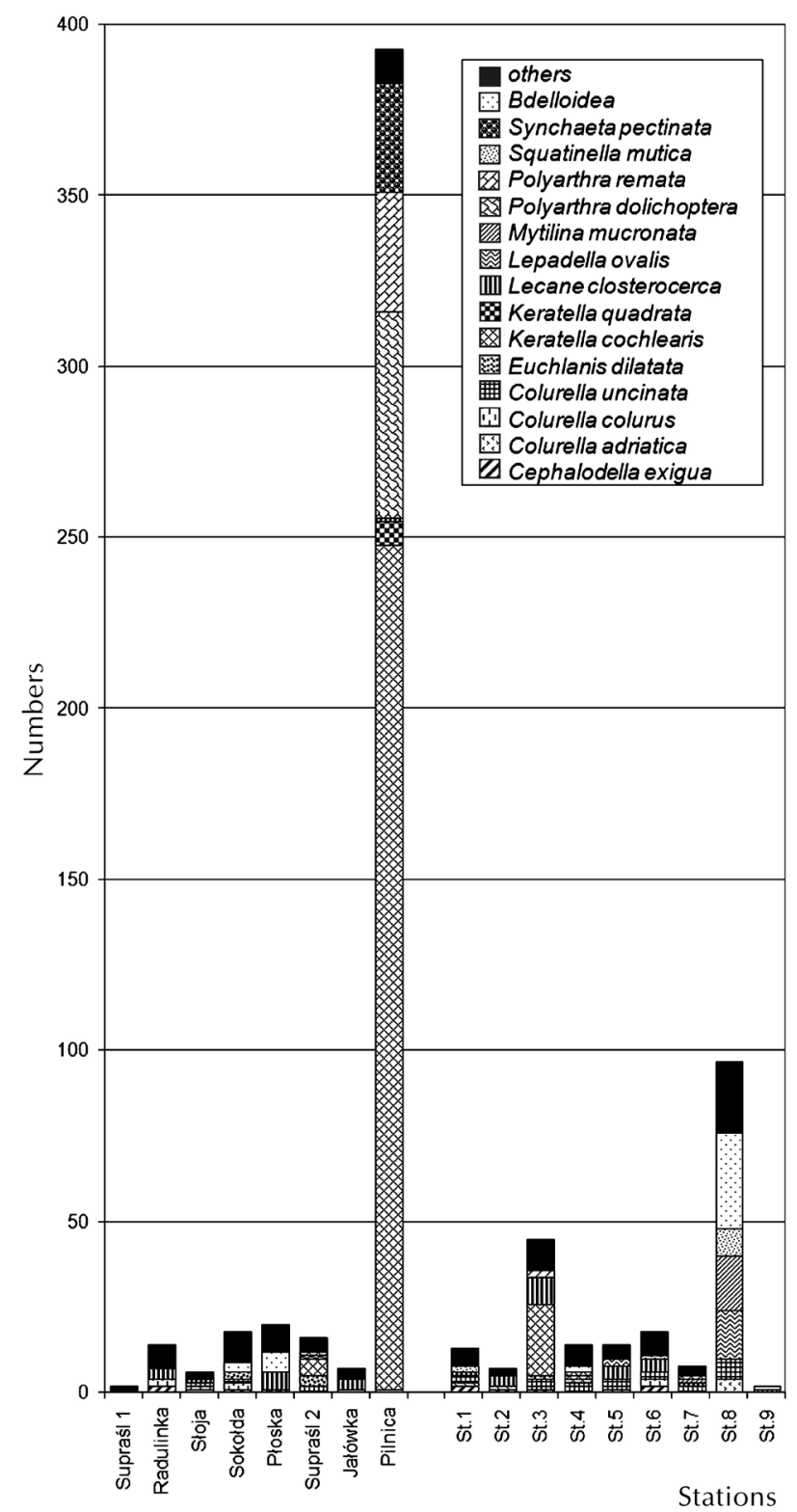

Fig. 3. Numbers of Rotifera (ind. $\mathrm{dm}^{-3}$ ) in the water current at particular stations of the rivers under study in September 2007

Table 2. Percentage similarity (PSC) of rotifer communities from water vegetation and river current at the same stations

\begin{tabular}{lccc}
\hline \multicolumn{1}{c}{ Rivers } & \multicolumn{2}{c}{ Rudnia } \\
\hline \multicolumn{1}{c}{ Station } & PSC & Station & PSC \\
\hline Supraśl 1 & 0.0 & No. 1 & 16.3 \\
Radulinka & 32.5 & No. 2 & 36.2 \\
Słoja & 32.8 & No. 3 & 30.0 \\
Sokołda & 24.0 & No. 4 & 0.0 \\
Ploska & 26.1 & No. 5 & 26.0 \\
Supraśl 2 & 9.1 & No. 6 & 23.6 \\
Jałówka & 43.4 & No. 7 & 15.6 \\
Pilnica & 5.4 & No. 8 & 4.3 \\
& & No. 9 & 2.1 \\
Mean (SD) & $21.7(15.3)$ & & $17.1(12.9)$ \\
\hline
\end{tabular}

The percentage similarity of rotifer communities in the river drift calculated for all possible pairs of the stations was relatively low and markedly lower in RIVERS (10.8\%) than in RUDNIA (17.8\%). Despite these differences, epiphytic rotifer communities in RIVERS were similar in $33.0 \%$ of cases, whereas those from different stations of RUDNIA in $34.4 \%$ (Fig. 4). Thus, even if drifting communities are more similar it is not reflected in the similarity of neighbouring epihyton.

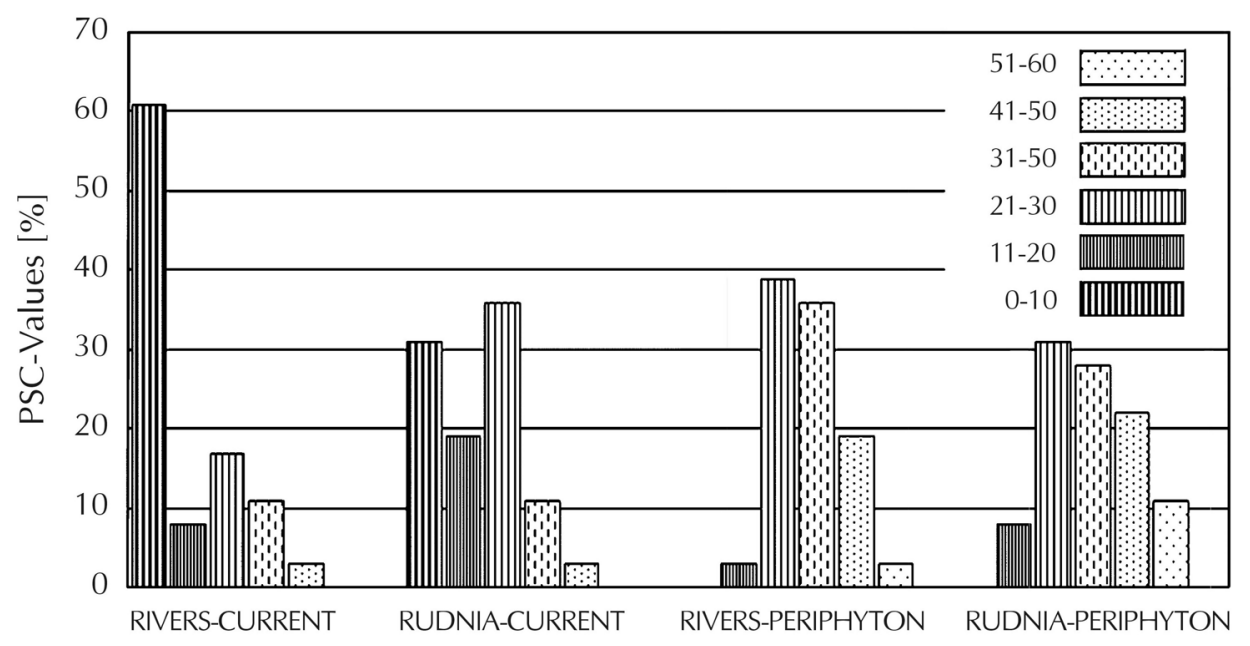

Fig. 4. Frequency of 6 classes of values of percentage similarity of community (PSC) indices calculated for all possible pairs of the small rivers under study 
Faunal originality of rotifer assemblages in RIVER and RUDNIA was also similar, except the station on the Słoja River (Fig. 5). The station differed from all the remaining stations in the number of species, which was extremely high, and originality of the rotifer composition. It resulted from the very high number of single specimens of rotifer species absent at other stations. The IFO index ranged from 0.22 to 0.53 in RIVERS and from 0.27 to 0.37 in RUDNIA. In this case also, the differences were not significant statistically $(P=0.23)$.

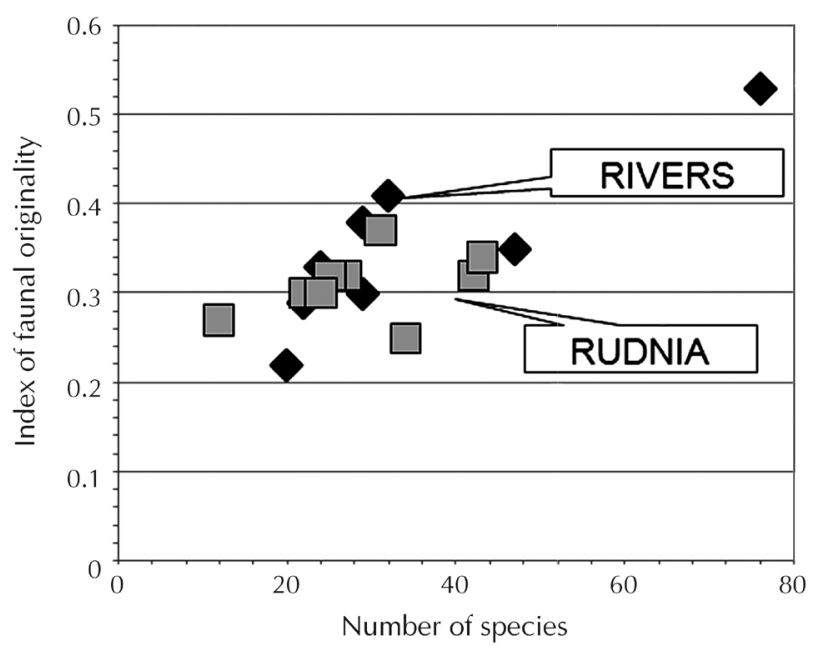

Fig.5. The relationship between number of rotifer species and values of the index of faunal originality for epiphytic communities of Rotifera at particular stations of all rivers under study

\section{Discussion}

The very low percentage similarity for communities from vegetation and the neighbouring water current suggests that species composition of communities of epiphytic rotifer fauna has a rather low impact on species structure of rotifer communities in water drift. The set of individuals of different species carried with the water current is random and different at different stations. This statement is well illustrated with a lack of significant differences between stations located in different rivers and those from the same river (Table 2). Although total number of rotifer species, number of species at particular stations, percentage similarity of periphytic rotifer communities for all possible pairs of stations and index of faunal originality are always slightly higher in RIVERS (Table 3), the differences between RIVERS and RUDNIA were insignificant in all the cases mentioned above. It confirms the results of Horner and Welch's (1981) studies, which seem to show that heterotrophs are favoured relative to autotrophs by velocity increases. The authors explain that as a greater ability of animal members of periphyton to cling to the substrate and thus exist in relatively greater abundance in fast currents. However, they believe that decomposers may colonize the newly cleaned substrate more readily than producers.

The role of aquatic vegetation in increasing species diversity of rotifer communities inhabiting them is well known. The littoral macrophyte beds reduce water movements, which allows more time for rotifers to grow and reproduce (Lair 1980, Basu et al. 2000). Therefore Shurpyt and Stelzer (2009) suggest that

Table 3. Comparison of rotifer communities inhabiting water vegetation in small rivers under study

\begin{tabular}{|c|c|c|c|}
\hline & & RIVERS & RUDNIA \\
\hline \multirow{2}{*}{ Total number of rotifers, ind. $\mathrm{g}^{-1} \mathrm{DW}$} & mean & 1516 & 1607 \\
\hline & range & $253-4291$ & $78-7349$ \\
\hline \multirow{2}{*}{ Total number of Monogononta, ind. $\mathrm{g}^{-1} \mathrm{DW}$} & mean & 1008 & 630 \\
\hline & range & $145-3470$ & $16-2136$ \\
\hline Total number of rotifer species & & 107 & 83 \\
\hline \multirow{2}{*}{ Number of species at particular stations } & mean & 35 & 29 \\
\hline & range & $20-76$ & $12-42$ \\
\hline \multirow{2}{*}{$\begin{array}{l}\text { Percentage similarity of periphytic rotifer communities for all possible } \\
\text { pairs of stations }\end{array}$} & mean & 33.0 & 34.4 \\
\hline & range & $15.08-56.0$ & $12.6-56.0$ \\
\hline \multirow{2}{*}{ Index of faunal originality } & mean & 0.35 & 0.31 \\
\hline & range & $0.22-0.53$ & $0.25-0.37$ \\
\hline
\end{tabular}


plant beds represent hot spots for invertebrate abundance in streams.

Manipulation with three artificial sources of habitat structure in experiments carried out by Downes et al. (1998) in a stony, upland stream allows the authors to state that each element of habitat structure promoted both increased species richness and densities of macroinvertebrates. The authors suggest that species richness in stream communities is regulated in a local scale even if faunal composition changes continually.

Taking into consideration both literature statements and results of these studies it may be emphasized that small first- or second-order rivers resemble strings of beads. River current plays the role of the string in maintaining a specific structure of the river biota, whereas vegetation "beads" create separated habitats for epiphytic communities of aquatic fauna rich in species.

\section{Acknowledgements}

This work was part-funded by the Polish Ministry of Science and Higher Education project no. 3T09D06929.

\section{References}

Basu B.K., Kalff J., Pinel-Alloul B., 2000, The influence of macrophyte beds on plankton communities and their export from fluvial lakes in the St Lawrence River, Freshwater Biol. 45: 373-382.
Downes B.J., Lake P.S., Schreiber E. S.G., Glaister A., 1998, Habitat structure and regulation of local species diversity in a stony, upland stream, Ecol. Monogr. 68: 237-257.

Duggan I.C., 2001, The ecology of periphytic rotifers, Hydrobiologia 446/447: 139-148.

Erben R., 1987, Rotifer fauna in the periphyton of Karst rivers in Croatia, Yugoslavia, Hydrobiologia 147: 103-105.

Horner R.R., Welch E.B., 1981, Stream periphyton development in relation to current velocity and nutrients, Can. J. Fish. Aquat. Sci. 38: 449-457.

Lair N., 1980, The rotifer fauna of the River Loire (France) at the level of the nuclear power plants, Hydrobiologia 73: 153-160.

Lair N., Reyes-Marchant P., 1997, The potamoplankton of the Middle Loire and the role of the "moving littoral" in downstream transfer of algae and rotifers, Hydrobiologia 356: 33-52.

Modenutti B.E., Claps M.C., 1989, Monogononta rotifers from plankton and periphyton of pampasic lotic environments (Argentina), Limnologica 19: 167-175.

Nielsen D.L., Watson G., 2008, The response of epibenthic rotifers and microcrustacean communities to flow manipulations in lowland rivers, Hydrobiologia, 603: 117128.

Puchalski W., 1987, Ugrupowania fitoplanktonu poeksploatacyjnych zbiorników wodnych (Phytoplankton assemblages in after-exploitation reservoirs) [Dissertation], Institute of Ecology PAS, Dziekanów Leśny, p. 205 (in Polish).

Shupryt M.P., Stelzer R.S., 2009, Macrophyte beds contribute disproportionately to benthic invertebrate abundance and biomass in a sand plains stream, Hydrobiologia 632: 329-339.

Whittaker. R.H., Fairbanks C.W., 1958, A study of plankton copepod communities in the Columbia Basin, Southeastern Washington, Ecology 39: 46-65. 